\title{
The Effect of Consumer Decision Making Style on Retail Format ChoiceBehavior: A Study from Sukkur, Pakistan.
}

Muhammad Saleh Memon

Assistant Professor, Department of Business Administration, Shah Abdul Latif University, Khairpur Mir's, Sindh, Pakistan.

saleh.memon@salu.edu.pk

Ahmed Ali Mangrio

Lecturer, Department of Commerce, Government Islamia Arts \& Commerce College \& Post Graduate Studies

Centre, Sukkur, Sindh, Pakistan.

ahmed.mangrio@gmail.com

Amjad Ali Jatoi

amjadjatoi14@gmail.com

${ }^{\star}$ Corresponding Author.

\begin{abstract}
Research on exploring effects of Consumer Decision Making Style on Retail Format Choice Behavior and to study the effect of demographic factors on each factor of decision making style was conducted. The usable data of 116 respondents' was taken from the city of Sukkur in Pakistan. The multiple regression technique was used to explain the role of afore mentioned factors. Results conclude that only $7.9 \%$ is explained by Decision Making Styles on Retail Format Choice. And maximum of $18.7 \%$ is explained by four demographic factors on a Consumer Decision Making Style.
\end{abstract}

Keywords: Decision Making Style; Demographic; Psychographic; Retailing; Consumer Behavior; Pakistan.

\section{Council for Innovative Research}

Peer Review Research Publishing System

\section{Journal: INTERNATION JOURNAL OF COMPUTERS AND TECHNOLOGY}

Vol. 13, No. 5

editorijctonline@gmail.com

www.cirworld.org/journals 


\section{INTRODUCTION}

One aspect of consumer behavior is to study individuals, and the processes these persons use to select experiences is related with this study.There are three main consumer responses (a) emotional (b) mental and (c) behavioral responses(Kardes, Cronley, \& Cline, 2011). Out of all responses the outcome arrives as in the shape of decision making style. It is observed by (Sproles \& Kendall, 1986) that people tend to follow a short list of styles for decision making. That decision making style is defined as psychographic and lifestyle dimensions that shape the way to making consumer choices

(Mirza, 2010) has indicated that there is a considerable difference between the demographic attributes of a consumer which choose a particular retail format. There isrise in options for consumers for retail formatsin Pakistan with the upgrading of domestic retailers as well as with the entry of foreign firms in retail business. Therefore, for the days of increasing competition among retailers there is a dire need to answer that what format is preferable by different segments of consumers.

This trend requires that marketers must study the factors that influence the choice of retail format in different areas of Pakistan. The same trend is forwarding steadily in smaller cities like Sukkur, Larkana, Khairpur and others.Where local general stores are becoming superstores and neighborhoodkiryana ${ }^{1}$ stores are growing bigger. Alike study in India was conducted by (Prasad \& Aryasri, 2011) but our study choose somehow different psychographic factors that influenced retail format choice.

The city of Sukkur is located at the right bank of Indus. This is one of very ancient cities in the Indus Valley Civilization. This city is seeing the rise of different specialty and general grocery superstores like ICON by Ghouri's, Stylo, Riwaj, and Almas and count on. There is also good presence of government owned Utility Stores in the city. The general observation by author reveal that the high earning population of Sukkur is more likely to go to shopping in once or twice in a month with family for grocery shopping to a superstore. Where all family members purchase their products on their own wish. The location of superstore is most influential factor to attract shoppers as the success of ICONby Ghouri's ${ }^{2}$ indicates.

And very important to mention the wholesale markets present in heart of city which provide the wholesale-cum-retail services to all the population at least in the radius of $150 \mathrm{KMs}$, in an expert opinion. As with the changes in general economic indicators, customer preferences and other variables the authors of this article, who are living in Sukkur, are also experiencing change in the retail structure in the city. It is generally believed that usually government employees try to purchase their groceries once in a month from wholesale market. But the persons who have handsome earning prefer to go to superstores.

The basic purpose of this study is to establish a link between consumers' decision making style and retail format choice behaviour in the city of Sukkur, Pakistan. The basic research questions (RQ) are:

RQ1: Does the choice of retail format is affected by decision making style.

RQ2: Does different demographic factors impact upon decision making style.

\section{LITERATURE REVIEW}

Research by(Mirza, 2010) has studied only demographic factors influencing the choice of retail format in a large metropolitian city, i.e., Karachi. She concluded that at least eight demographic factors contribute significantly for the choice of retail format. And suggested that a similar or more advanced study can be taken to study the same factors or be combined with psychographic factors in the smaller towns in Pakistan to pave the way for research on psychographics for retail format choice studies in Pakistan. Therefore in this study we are applying both demographic and psychographic factors influencing retail format choice in a small city of Pakistan, i.e., Sukkur.

(Ministry of Finance, 2013) has reported that second largest employement source is Wholesale and Retail Trade Sector. Which alone providing employement to $16.15 \%$ (including $1.31 \%$ points for Hotels and Restaurants) of employed persons in 2010-11, after Agriculture \& Livestock Sector. And its share in GDP of 2012-13 is $18.2 \%$, being first in Service Sector whereas Agriculture accounted for $21.4 \%$ and whole Industrial Sector was contributing for $20.9 \%$. The Wholesale and Retail sector has demonstrated a growth of $2.5 \%$ in $2012-13$ over the previous year. The discussion upon true potential in retailing in Pakistan is done by (Sadiq, 2012). He conculded that this sector can generate upto $\$ 42$ Billion per year. And food sector among them is most attractive sector for for next five years.

(Prasad \& Aryasri, 2011) studied the psychographic factors involved in retail format choice behaviour in India. They concluded that both demographic as well as psychographic factors contribute significantly for retail format choice behaviour. But we are researching on only one psychografic factor i.e., Consumers Decision-making Style. We used a set of questions as shortlisted by (Shim, 1996)from (Sproles \& Kendall, 1986) consumer style inventory (CSI). The importance of this shortlisted inventory cannot be undervalued because (Google, 2014) has found 135 citations to (Shim, 1996)and 562 citations to the original developers of the inventory.

\footnotetext{
${ }^{1}$ Kiryana Store is a neighborhood general grocery store in old or traditional style with easy credit terms, mostly found in rural and suburban areas. Today's most general stores has upgraded gradually from kiryana stores.

${ }^{2}$ ICON by Ghouri's is a Superstore located at the scenic view near the Tomb of Mir Masoom Shah - a famous historical site in Sukkur.
} 
The same set of questions was previously used upon the respondents in the study by (Bao, Zhou, \& Su, 2003). They evaluated the effect of consumers decision making style cross culturally. Their purpose was to identifythe impact of/on face conciousness and risk aversion for US and China. They concluded that customers among both countires differ significantly in decision making styles, and possibly due the the traits developed by culture.

\section{METHODOLOGY}

For the measurement of decision making style we used ashortlisted version as modified by (Shim, 1996)of Structured Questionnaire of (Sproles \& Kendall, 1986) Consumer Style Inventory (CSI). We have taken only 32 questions from CSI, four questions for each of all eight factors in CSI. Questions were re-ordered randomly. Each question was measured on 5-point Likert Scale being 1 equals Strongly Disagree to 5 for Strongly Agree. It is a priori to say that higher value shows higher inclination toward that factor.

A statafied sample of 125 respondents were taken from different educational and other institutes in Sukkur. We tried to cover all income classes and the persons which used different retail formats like (a) General Store, (b) Neighbourhood Kiryana Store, (c) Superstore or Departmental Store, (d) Governement owned Utility Store, and (e) Wholesale-cum-Retail Store. The eight decision making styles that effect shoppers' choice of retail format are (a) Perfectionistic and high-qualityconscious consumer (PHQCC), (b) Brand-conscious and price-equals-quality consumer (BCPEQC), (c) Novelty and fashion-conscious consumer (NFCC), (d) Recreational and hedonistic consumer (RHC), (e) Price-conscious and value-formoney consumer (PCVMC), (f) Impulsive and careless consumer (ICC), (g) Confused by over-choice consumer (COCC), and (h) Habitual and Brand Loyal Consumer (HBLC).Only 116 usable records were processed for the analysis in SPSS v16 over Sony VaioCore i3 2.4GHz processor with 4GB RAM in Windows 7 Home Premium 64bit.

We used multiple regression for observing the effect of decision making style on different retail formats. The smaller stores like Kiryana and General Stores were coded with smaller values. And large size or volume leaders like Superstore, Wholesale and Utility Stores were assigned with higher values in the variable RTFMT (See RQ1).

Model 1:

$$
R T F M T=\alpha+\beta_{1} P H Q C C+\beta_{2} B C P E Q C+\beta_{3} N F C C+\beta_{4} R H C+\beta_{5} P C V M C+\beta_{6} I C C+\beta_{7} C O C C+\beta_{8} H B L C+\mu
$$

We further used multiple regressionModel 2 to 9 to measure the effects of ordinal variables - Age, Education Level (EDU), Monthly Income (INC), and Family Members (FMEM) as independent variables - upon each of the eight factors of decision-making style as dependent variable(See RQ2). An example of Model 2 follows herewith:

\section{Model 2:}

\section{RESULTS}

$$
P H Q C C=\alpha+\beta_{1} E D U+\beta_{2} A G E+\beta_{3} F M E M+\beta_{4} I N C+\mu
$$

Most of respondents were found educated because the authors mostly relied on students and faculty at educational institutes and employees in banks. That group was mostly found below 40 years of age. But the sample appears to be well stratified for family size, and Income. There is dominance of wholesalers as a preferred choice for the most of respondents in Sukkur because this city is well known for its wholesale markets. 
Table 1: Respondents' Profile

\begin{tabular}{|c|c|c|c|}
\hline Variables & & $n=116$ & $\%$ \\
\hline Education & $\begin{array}{l}\text { Below Primary } \\
\text { Primary Education } \\
\text { Secondary Education } \\
\text { Graduate \& Above }\end{array}$ & $\begin{array}{r}3 \\
3 \\
9 \\
101\end{array}$ & $\begin{array}{r}2.6 \\
2.6 \\
7.8 \\
87.1\end{array}$ \\
\hline Age & $\begin{array}{l}\text { Below } 25 \text { years } \\
26 \text { - } 40 \text { years } \\
41 \text { - } 50 \text { years } \\
\text { Above } 51 \text { years }\end{array}$ & $\begin{array}{r}43 \\
59 \\
10 \\
4\end{array}$ & $\begin{array}{r}37.1 \\
50.9 \\
8.6 \\
3.4\end{array}$ \\
\hline Family Members & $\begin{array}{l}\text { or } 2 \\
3 \text { or } 4 \\
5 \text { or } 6 \\
\text { Above } 6\end{array}$ & $\begin{array}{l}10 \\
28 \\
34 \\
44\end{array}$ & $\begin{array}{r}8.6 \\
24.1 \\
29.3 \\
37.9\end{array}$ \\
\hline Monthly Income & $\begin{array}{l}\text { Below } 15000 \\
15001-30000 \\
30001-60000 \\
\text { Above } 60001\end{array}$ & $\begin{array}{l}32 \\
33 \\
34 \\
17\end{array}$ & $\begin{array}{l}27.6 \\
28.4 \\
29.3 \\
14.7\end{array}$ \\
\hline Gender & $\begin{array}{l}\text { Male } \\
\text { Female }\end{array}$ & $\begin{array}{l}74 \\
42\end{array}$ & $\begin{array}{l}63.8 \\
36.2\end{array}$ \\
\hline Marital Status & $\begin{array}{l}\text { Single } \\
\text { Married }\end{array}$ & $\begin{array}{l}60 \\
56\end{array}$ & $\begin{array}{l}51.7 \\
48.3\end{array}$ \\
\hline Occupation & $\begin{array}{l}\text { Govt. Job } \\
\text { Private Job } \\
\text { Businessman } \\
\text { Housewife } \\
\text { Student } \\
\text { Other }\end{array}$ & $\begin{array}{r}49 \\
24 \\
7 \\
6 \\
26\end{array}$ & $\begin{array}{r}42.2 \\
20.7 \\
6 \\
5.2 \\
22.4 \\
3.4\end{array}$ \\
\hline $\begin{array}{l}\text { Often used retail format } \\
\text { (RTFMT) }\end{array}$ & $\begin{array}{l}\text { General Store } \\
\text { Kiryana Store } \\
\text { Superstore } \\
\text { Utility Store } \\
\text { Wholesale Store }\end{array}$ & $\begin{array}{r}19 \\
19 \\
35 \\
4 \\
39\end{array}$ & $\begin{array}{r}16.4 \\
16.4 \\
30.2 \\
3.4 \\
33.6\end{array}$ \\
\hline
\end{tabular}

The reliability analysis did not produced completely favorable results. Though it is considered that Cronbach's Alpha values from 0.6 to 0.89 are acceptable for an exploratory research (Nunnally, 1978). We feel that the lower reliability results can be attributed to data collection tool which was administered in as-it-is format from CSI in a non-local language i.e., English. 
Table 2: Reliability Analysis

\begin{tabular}{|c|c|c|}
\hline Q\# & Decision-Making Style & $\begin{array}{c}\text { Cronbach's } \\
\text { Alpha }\end{array}$ \\
\hline \multirow[b]{2}{*}{$\begin{array}{l}9 \\
16 \\
27 \\
25\end{array}$} & Perfectionistic and high-quality-conscious consumer & \multirow[t]{2}{*}{0.532} \\
\hline & $\begin{array}{l}\text { Getting very good quality is very important to me. } \\
\text { When it comes to purchasing products, I try to get the very best or perfect choice. } \\
\text { In general, I usually try to buy the very best over-all quality products. } \\
\text { I make special effort to choose the very best quality products. }\end{array}$ & \\
\hline \multirow[b]{2}{*}{$\begin{array}{r}6 \\
19 \\
13 \\
24\end{array}$} & Brand-conscious and price-equals-quality consumer & \multirow[t]{2}{*}{0.477} \\
\hline & $\begin{array}{l}\text { The well-known national brands are best for me. } \\
\text { The more expensive brands are usually my choices. } \\
\text { The higher the price of a product, the better its quality. } \\
\text { Nice department and specialty stores offer me the best products. }\end{array}$ & \\
\hline \multirow[b]{2}{*}{$\begin{array}{l}26 \\
14 \\
10\end{array}$} & Novelty and fashion-conscious consumer & \multirow[t]{2}{*}{0.605} \\
\hline & $\begin{array}{l}\text { I usually have one or more outfits of the very newest style. } \\
\text { I keep my wardrobe up-to-date with the changing fashions. } \\
\text { Fashionable, attractive styling is very important to me. } \\
\text { For variety, I shop different stores and choose different brands. }\end{array}$ & \\
\hline \multirow[b]{2}{*}{$\begin{array}{l}7 \\
30 \\
23 \\
4\end{array}$} & Recreational and hedonistic consumer & \multirow[t]{2}{*}{0.753} \\
\hline & $\begin{array}{l}\text { Shopping is a pleasant activity to me. } \\
\text { Going shopping is one of the enjoyable activities of my life. } \\
\text { It is worth my time to shop the stores. } \\
\text { I enjoy shopping just for the fun of it. }\end{array}$ & \\
\hline \multirow[b]{2}{*}{$\begin{array}{l}12 \\
20 \\
22 \\
17\end{array}$} & Price-conscious and value-for-money consumer & \multirow[t]{2}{*}{0.496} \\
\hline & $\begin{array}{l}\text { I buy as much as possible at sale prices. } \\
\text { The lower-price products are usually my choice. } \\
\text { I look carefully to find the best value for the money. } \\
\text { I compare prices to find the lower-priced products. }\end{array}$ & \\
\hline \multirow[b]{2}{*}{$\begin{array}{l}28 \\
11 \\
29 \\
31\end{array}$} & Impulsive and careless consumer & \multirow[t]{2}{*}{0.281} \\
\hline & $\begin{array}{l}\text { I should plan my shopping more carefully than I do. } \\
\text { I am impulsive when purchasing. } \\
\text { I often make careless purchases I later wish I had not. } \\
\text { I don't spend much time shopping for best buys. }\end{array}$ & \\
\hline \multirow[b]{2}{*}{$\begin{array}{l}8 \\
15 \\
21 \\
5\end{array}$} & Confused by over-choice consumer & \multirow[t]{2}{*}{0.512} \\
\hline & $\begin{array}{l}\text { There are so many brands to choose from that I often feel confused. } \\
\text { Sometimes it's hard to choose which stores to shop. } \\
\text { The more I learn about products, the harder it seems to choose the best. } \\
\text { All the information I get on different products confuses me. }\end{array}$ & \\
\hline \multirow[b]{2}{*}{$\begin{array}{c}18 \\
32 \\
1\end{array}$} & Habitual and brand-loyal consumer & \multirow[t]{2}{*}{0.586} \\
\hline & $\begin{array}{l}\text { I have favourite brands I buy over and over. } \\
\text { Once I find a product or brand I like, I stick with it. } \\
\text { I go to the same stores each time I shop. } \\
\text { I am loyal to certain stores and brands. }\end{array}$ & \\
\hline
\end{tabular}


The factor method was used to reduce the data of 32 style variables as mentioned in Table 2 to 8 variables. The Model 1 results tells us that only $7.9 \%$ is explained by decision making style variables for selection of retail format. Still $92.1 \%$ remains to be explained by other factors which are not in the scope of this study. Further research can be done for exploration of factors responsible for retail format choice. These factors could be from consumer side or from retailer side.

Table 3: Regression Results using Model 1.

\begin{tabular}{|c|c|c|c|}
\hline $\mathbf{R}$ & $\mathbf{R}$ Square & Adjusted R Square & Std. Error of the Estimate \\
\hline 0.280 & 0.079 & 0.010 & 1.466 \\
\hline
\end{tabular}

Table 4: Regression Results (Coefficients) using Model 1.

\begin{tabular}{|c|c|c|c|c|c|}
\hline \multirow{2}{*}{ Model 1} & \multicolumn{2}{|c|}{ Unstandardized Coefficients } & \multirow{2}{*}{$\begin{array}{c}\text { Standardized Coefficients } \\
\text { Beta }\end{array}$} & \multirow{2}{*}{$\mathbf{t}$} & \multirow{2}{*}{ Sig. } \\
\hline & B & Std. Error & & & \\
\hline (Constant) & 3.216 & 0.136 & & 23.621 & 0.000 \\
\hline PHQCC & 0.027 & 0.154 & 0.018 & 0.173 & 0.863 \\
\hline BCPEQC & 0.083 & 0.158 & 0.056 & 0.527 & 0.600 \\
\hline NFCC & -0.052 & 0.158 & -0.035 & -0.328 & 0.744 \\
\hline $\mathrm{RHC}$ & -0.440 & 0.182 & -0.299 & -2.422 & 0.017 \\
\hline PCVMC & 0.163 & 0.168 & 0.111 & 0.968 & 0.335 \\
\hline ICC & 0.106 & 0.152 & 0.072 & 0.696 & 0.488 \\
\hline COCC & 0.064 & 0.153 & 0.044 & 0.419 & 0.676 \\
\hline HBLC & 0.090 & 0.156 & 0.061 & 0.581 & 0.562 \\
\hline
\end{tabular}

The Model 2 results show that four demographic factors (all ordinal) has explained only $7.2 \%$ on the Price and High Quality Consciousness among respondents. The Figure 1 shows the summary of Beta values for results of Model 1 to 9.

Table 5: Regression Results using Model 2.

\begin{tabular}{|c|c|c|c|}
\hline $\mathbf{R}$ & R Square & Adjusted R Square & Std. Error of the Estimate \\
\hline 0.269 & 0.072 & 0.039 & 0.980 \\
\hline
\end{tabular}

Table 6: Regression Results (Coefficients) using Model 2.

\begin{tabular}{|l|r|r|r|r|r|}
\hline \multirow{2}{*}{ Model 2 } & \multicolumn{2}{|c|}{ Unstandardized Coefficients } & \multicolumn{1}{c|}{$\begin{array}{c}\text { Standardized } \\
\text { Coefficients }\end{array}$} & \multicolumn{1}{c|}{$\mathbf{t}$} & \multirow{2}{*}{ Sig. } \\
\cline { 2 - 4 } & B & Std. Error & Beta & \\
\hline (Constant) & 0.065 & 0.759 & & 0.086 & 0.931 \\
\hline EDU & -0.101 & 0.158 & -0.062 & -0.637 & 0.525 \\
\hline AGE & -0.109 & 0.144 & -0.081 & -0.760 & 0.449 \\
\hline FMEM & 0.211 & 0.096 & 0.208 & 2.201 & 0.030 \\
\hline INC & -0.049 & 0.105 & -0.051 & -0.469 & 0.640 \\
\hline
\end{tabular}


Figure 1: Direction of Relations among Regression Results.

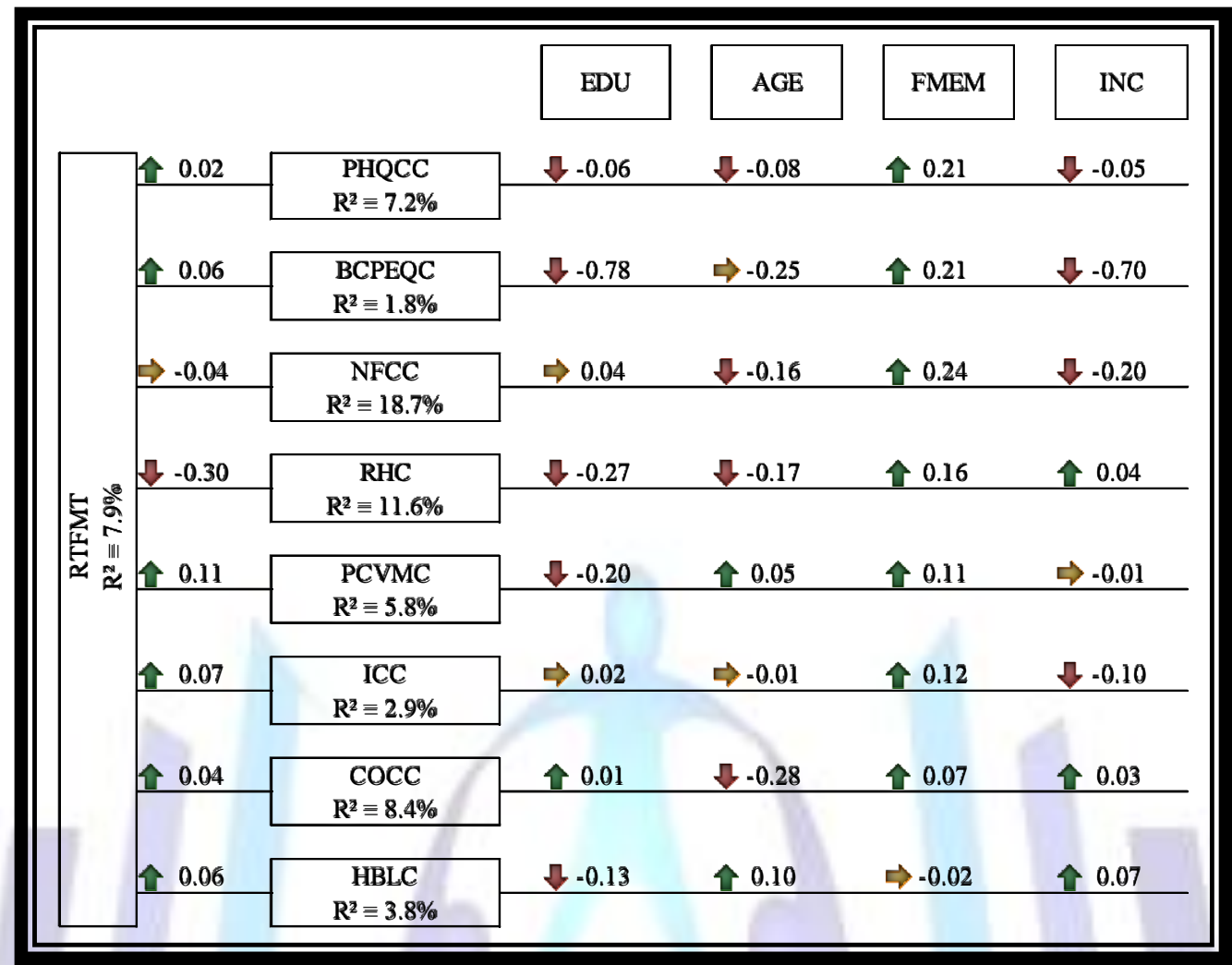

\section{CONCLUSION}

This study was conducted to measure the effect of Consumer Decision Making Style (using CSI as tool) on Retail Format Choice Decision in Sukkur. The results revealed an insignificant existence of relationship that was explained below $8 \%$ by Decision Making Style on Decision for choosing retail format. The further exploration by taking eight Decision Making Styles as dependent variables and demographic variables as independent variables has explained not more than $19 \%$. We suggest that the modification and translation of CSI may improve using some other techniques. A scale-type variable instead of ordinal can be used for demographic factors. We further suggest exploration on effects of store related factors on choice of retail format in different cities of Pakistan.

\section{REFERENCES}

1. Bao, Y., Zhou, K. Z., \& Su, C. (2003). Face consciousness and risk aversion: Do they affect consumer decisionmaking? Psychology and Marketing, 20(8), 733-755. doi:10.1002/mar.10094

2. Google. (2014). Google Scholar Website. Google Schoalr. Retrieved from http://scholar.google.com.pk/scholar?cites $=18442374513410758143 \&$ as_sdt=2005\&sciodt=0,5\&hl=en

3. Kardes, F. R., Cronley, M. L., \& Cline, T. W. (2011). Consumer Behavior (pp. 8-11). South West Cengage Learning.

4. Ministry of Finance. (2013). Economic Survey of Pakistan 2012-13. Islamabad. Retrieved from http://www.finance.gov.pk/

5. Mirza, S. (2010). The influence of Demographic factors on the choice of retail outlet selected for food and grocery purchases by urban Pakistanis . In Proceedings of the International Conference on Business and Economic Research (pp. 1-16). Kuching Sarawak, Malaysia: International Conference on Business and Economic Research.

6. Nunnallly, J. C. (1978). Psychometric Theory. New York: McGraw Hill.

7. Prasad, C. J., \& Aryasri, A. R. (2011). Effect of shopper attributes on retail format choice behaviour for food and grocery retailing in India. International Journal of Retail \& Distribution Management, 39(1), 68-86.

doi:10.1108/09590551111104486

8. Sadiq, I. (2012). Economic Impact of Retailing in Pakistan. In Proceedings of the 2nd International Conference on Business Management. Lahore, Pakistan.

9. Shim, S. (1996). Adolescent consumer decision-making styles: The consumer socialization perspective. Psychology and Marketing, 13(6), 547-569. doi:10.1002/(SICl)1520-6793(199609)13:6<547::AID-MAR2>3.0.CO;2-8 
10. G. B., \& Kendall, E. L. (1986). A Methodology for Profiling Consumers' Decision-Making Styles. Journal of Consumer Affairs, 20(2), 267-279. doi:10.1111/j.1745-6606.1986.tb00382.x

\section{Author's Biography}

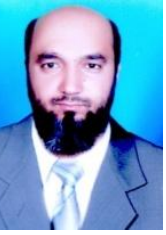

"Completed my MBA from Shah Abdul Latif University Khairpur, Sindh Pakistan in Finance and appointed as lecturer there in september 2004 and completed my M. Phil in Finance from IQRA University Karachi in 2010 and promoted as Assistant Professor, now recently submitted my Ph.D thesis for foreign evaluation from Shah Abdul Latif University Khairpur in Public finance under the supervision of Dr. Syed Munir Ahmed Shah". 